\title{
Fungsi Humas Desa Sebagai Pengelola Informasi di Era Keterbukaan Informasi Publik
}

\author{
Dikhorir Afnan \\ Universitas Muhammadiyah Cirebon \\ Email: dikhorir@umc.ac.id
}

\begin{abstract}
Information management and documentation activities are an integral part of an institution or organization. This activity is directly related to the function of top management. Public information openness is an aspect of democracy that upholds freedom and human rights in obtaining correct information. Efforts to continually improve services and manage information for their institutions, encourage feelers and the public to organize government programs, both at the village, provincial and central levels. In the journal entitled "The Government Public Relations Function as Information Manager in The Era of Public Information Disclosure", the writer uses a qualitative research methodology approach. Qualitative research can also be called descriptive research, where the collected data prioritizes words or images. Data was collected through a purposive sampling technique to information and documentation managers in Kasugengan Kidul Village, Depok District, Cirebon Regency. The results of the study indicate that each village apparatus has a role as a village public relations or information manager who is obliged to provide information clearly to the community. Efforts to develop community independence and prosperity by increasing knowledge, attitudes, skills, behaviors, abilities, awareness, and utilizing resources through the establishment of policies, programs, activities, and assistance that are in line with the essence of the problem and the priority of the needs of the village community useful. The conclusion of this study is that information managers in Kasugengan Kidul Village have been able to make a positive contribution in the dissemination of village government work programs. The central, provincial, district / city, village and community governments essentially have the same goal in developing the potential and development of the village based on the principle of transparency and jointly supervise the implementation in a participatory manner.

Keywords: Public Information Openness, Village Government Public Relations, Information and Documentation Management Officer. Information Transparency.
\end{abstract}

\begin{abstract}
Abstrak. Aktivitas pengelolaan informasi dan dokumentasi adalah bagian integral dari suatu kelembagaan atau organisasi. Aktivitas ini terkait langsung dengan fungsi manajemen puncak. Keterbukaan informasi publik adalah aspek demokrasi yang menjunjung tinggi kebebasan dan hak asasi manusia dalam memperoleh informasi yang benar. Upaya peningkatan pelayanan secara kontinyu dan pengelolaan informasi bagi instansinya, mendorong perasa serta masyarakat dalam menyuseskan program pemerintah, baik di tingkat desa, provinsi, maupun pusat. Pada jurnal berjudul "Fungsi Humas Desa sebagai Pengelola Informasi di Era Keterbukaan Informasi Publik" ini penulis menggunakan pendekatan metodologi penelitian kualitatif. Penelitian kualitatif dapat disebut juga dengan penelitian deskriptif, di mana data yang terkumpul lebih mengedepankan kata-kata atau gambar. Data dikumpulkan melalui teknik purposive sampling terhadap pengelola informasi dan dokumentasi yang ada di Desa Kasugengan Kidul Kecamatan Depok Kabupaten Cirebon. Hasil penelitian menunjukkan bahwa setiap perangkat desa difungsikan perannya sebagai humas desa atau pengelola informasi yang berkewajiban memberikan informasi secara jelas kepada masyarakat. Upaya mengembangkan kemandirian dan kesejahteraan masyarakat dengan meningkatkan pengetahuan, sikap, keterampilan, perilaku, kemampuan, kesadaran, serta memanfaatkan sumber daya melalui penetapan kebijakan, program, kegiatan, dan pendampingan yang sesuai dengan esensi masalah dan prioritas kebutuhan masyarakat desa ini diharapkan menghasilkan kondisi masyarakat yang berdaya guna. Kesimpulan penelitian ini adalah pengelola informasi di Desa Kasugengan Kidul telah mampu memberikan kontribusi positif dalam penyebaran program kerja pemerintah desa. Pemerintah pusat, provinsi, kabupaten/kota, desa, dan masyarakat hakikatnya memiliki tujuan yang sama dalam mengembangkan potensi dan pembangunan desa berdasarkan asas transparansi serta sama-sama melakukan pengawasan penyelenggaraannya secara partisipatif.

Kata Kunci: Keterbukaan Informasi Publik, Humas Pemerintahan Desa, Pejabat Pengelola Informasi dan Dokumentasi. Transparansi Informasi.
\end{abstract}




\section{A. PENDAHULUAN}

Sebagai sebuah kumpulan manusia, secara struktural fungsi humas merupakan bagian integral dari satu kelembagaan atau organisasi. Ada juga yang menyebut kehumasan sangat terkait langsung dengan fungsi manajemen puncak. Fungsi kehumasan dapat dikatakan berhasil jika berada di bawah pimpinan yang mempunyai hubungan langsung dengan pimpinan tertinggi (decission maker) pada organisasi/instansi bersangkutan. Keterbukaan informasi publik adalah aspek demokrasi yang menjunjung tinggi kebebasan dan hak asasi manusia dalam memperoleh informasi yang benar.

\section{Menurut}

Alfurkon

Setiawan, kepala Pusat Data dan Informasi, Sekretariat Kabinet RI, humas pemerintah juga diharapkan dapat meningkatkan pelayanan dan pengelolaan informasi di setiap instansinya, serta mampu mendorong partisipasi masyarakat dalam mensukseskan berbagai program pemerintah yang hasilnya dapat dinikmati oleh publik. Untuk meningkatkan kemampuan, kata Alfurkon, perangkat humas harus menguasai teknologi informasi dan komunikasi, termasuk di dalamnya media sosial sehingga dapat mengetahui kebutuhan publik.

Dalam tulisannya tersebut, Alfurkon juga mengutip definisi humas sebagaimana diungkapkan Scott $M$. Cutlip dan Allen H. Center; humas merupakan fungsi manajemen yang menilai sikap publik, mengidentifikasi kebijakan dan tata cara seseorang atau organisasi demi kepentingan publik, serta merencanakan dan melakukan suatu program kegiatan untuk memperoleh pengertian, pemahaman, dan dukungan dari publiknya.

Begitu juga seperti disampaikan
Menteri Komunikasi dan Informatika Rudiantara pada acara Forum Tematik Kehumasan yang bertema "Penguatan Kelembagaan Humas Pemerintah Pusat dan Daerah Untuk Mendukung Fungsi Government Public Relation" (GPR) pada 5 Maret 2015 di Aula Sekretariat Negara, bahwa kalangan humas harus mengubah pola pendekatan kepada masyarakat, yakni dari cara kuno ke modern yang lebih partisifatif. Selain itu, humas harus mengajak masyarakat menjadi bagian dari proses sehingga ada jalinan emosional dengan humas, dan masyarakat pun akan merasa memiliki tanggung jawab dan melakukan sharing kepedulian yang lebih banyak lagi (https://setkab.go.id/peran-humasdalam-mensukseskan-programpemerintah/. Dikutip pada 30 April 2019 pkl 07.34 WIB).

Keterbukaan Informasi Publik (KIP) sebagaimana tertuang dalam Undang-Undang No.14 tahun 2008 pada prinsipnya memberikan kewajiban kepada setiap badan publik untuk membuka akses bagi setiap pemohon informasi publik untuk mendapatkan informasi publik, kecuali beberapa informasi tertentu. UU KIP adalah salah satu produk hukum Indonesia yang dikeluarkan dalam tahun 2008 dan diundangkan pada tanggal 30 April 2008 dan efektif dua tahun setelahnya.

UU yang terdiri dari 64 pasal ini merupakan bagian dari program legislasi nasional inisiatif DPR periode 1999-2004. Jika melihat dari historisnya, proses advokasi UU ini memang cukup melelahkan karena prosesnya yang panjang. Ada sekitar 42 koalisi LSM yang bersepakat dan mendorong disahkannya UU ini. Secara substansi, tuntutan publik (LSM) terhadap pengesahan UU ini adalah untuk memantau tata kelola pemerintahan yang baik (good 
governance) yang mensyaratkan adanya akuntabilitas, tranparansi, dan partisipasi masyarakat dalam setiap proses terjadinya kebijakan publik.

Dari uraian di atas, penulis ingin meneliti sejauh mana humas di pemerintahan desa Kasugengan Kidul Kabupaten Cirebon ini dapat memerankan fungsinya dengan baik dalam menginformasikan programprogram pembangunan desa kepada masyarakat berdasarkan prinsip-prinsip transparansi.

\section{Identifikasi Masalah:}

1. Bagaimana perencanaan pengelolaan informasi desa dilaksanakan oleh humas desa/pengelola informasi dan dokumentasi desa?

2. Bagaimana pengelola informasi desa mengenalkan program kerja pemerintah desa secara transparan?

\section{Tujuan Penelitian:}

1. Ingin mengetahui perencanaan pengelolaan informasi desa dilaksanakan oleh humas desa/pengelola informasi dan dokumentasi desa.

2. Ingin mengetahui pengelola informasi desa mengenalkan program kerja pemerintah desa secara transparan.

\section{B. LANDASAN TEORETIS}

Soegiardjo (dalam Gassing, dkk. 2016:7) menyimpulkan definisi public relations $(P R)$ sebagaimana rumusan Griswold pada Forum $P R$ di New York 1947, bahwa $P R$ adalah fungsi manajemen yang melakukan penilaian terhadap sikap publik, menyesuaikan kebijaksanaan tata kerja dari suatu organisasi atau perorangan dengan kepentingan publik dan melakukan program aksi untuk memperoleh pengertian dan persetujuan publik.

Definisi tersebut menekankan pada aspek $P R$ sebagai fungsi manajemen dalam membantu organisasi, institusi atau perusahaan. Fungsi yang dimaksud adalah melakukan aksi kepada publik dengan tujuan memperoleh pengertian dan dukungan. Salah seorang tokoh $P R$ terkemuka yang kemudian disebut sebagai Bapak Public Relations, Edward Louis Bernays dalam bukunya "The Engineering of Consent (1955)", mendefinisikan PR sebagai "inducing the public to have understanding for and goodwill (membujuk publik untuk memiliki pengertian yang mendukung serta memiliki niat baik)".

Definisi tersebut memberikan pemahaman bahwa pada awalnya $P R$ bertugas membujuk publik untuk memiliki pengertian dan mendukung institusi. Dalam konteks ini, komunikasi dalam $P R$ lebih bersifat satu arah. Salain itu, Bernays juga menekankan persuasi sebagai bentuk pernyataan atau komunikasi yang dilakukan guna mengubah pendapat atau sikap publik.

Pandangan berbeda terjadi untuk humas yang cenderung dihubungkan dengan instansi pemerintah. Humas tersebut dipandang pasif ketika menghadapi opini dan sikap publik. Humas terkesan memberikan respons setelah mendapat kritik, bahkan resistensi. Misalnya, humas baru merespons setelah terjadi konflik, pemogokan, demonstrasi, bahkan setelah timbul kerusuhan.

Kinerja humas pemerintah seolah-olah hanya sebatas membuat release, mengadakan jumpa pers, menangkis informasi bernada negatif, mengkliping koran, dokumentasi, dan sebagainya. Tidak jarang humas dipandang tidak mempunyai perencanaan yang melibatkan profesional dan tidak mempunyai program kerja yang sistematis. Padahal, esensi 'hubungan' dengan 'masyarakat' 
bersifat dua arah.

Namun demikian, meskipun terdapat perbedaan, sudah seharusnya tidak perlu dipertentangkan kedua istilah tersebut. Pada dasarnya, kedua istilah itu berusaha menjembatani organisasi dan publik. Sebuah organisasi hanya dapat mencapai tujuan jika didukung publik. Semakin kuat dukungan dari publik, secara teori tujuan organisasi dapat dicapai dengan lebih mudah (Gassing, dkk. 2016:4-8).

Kepala Pusat Data dan Informasi, Sekretariat Kabinet RI, Alfurkon Setiawan menegaskan bahwa praktisi humas juga harus mampu menggunakan perangkat teknologi untuk mendistribusikan inforrmasi kepada publik secara cepat, tepat dan efektif. Kemampuan memanfaatkan kemajuan teknologi oleh praktisi humas juga sebagai jawaban dari tantangan perkembangan teknologi informasi dan komunikasi yang terus berubah dari waktu ke waktu.

Para praktisi humas, menurut Alfurkon, sedang memasuki masa kebangkitan dengan keberadaan teknologi informasi dan komunikasi. Keberadaannya membuat para praktisi humas mampu mencapai sasarannya kepada publik secara langsung tanpa intervensi pihak-pihak yang dapat menghambat kegiatan komunikasinya. Teknologi informasi dibutuhkan keberadaanya sebagai alat penunjang dan media. Dalam melaksanakan relasi/hubungan yang baik, penggunaan teknologi informasi dapat memberikan ruang bagi praktisi humas dalam merealisasikan tujuan yang ingin dicapai.

Selain itu, kata dia, teknologi komunikasi yang dapat digunakan dalam public relation adalah internet dan telepon. Internet bukan hanya sarana untuk mencari informasi, melainkan sarana yang baik untuk berkomunikasi. Misal, dengan e-mail, media social, website, semua kegiatan komunikasi dan hubungan dapat berjalan dengan lancar. Jadi dengan teknologi komunikasi, kemampuan untuk menyampaikan dan menerima pesan, jauh lebih mudah dan efektif (Dikutip https://setkab.go.id/peranhumas-dalam-mensukseskan-programpemerintah/. pada 30 April 2019 pkl 07.34 WIB).

Dalam Kamus Besar Bahasa Indonesia (KBBI), hak mengembangkan diri merupakan hak dari setiap orang untuk menjadikan diri lebih maju, baik pikirannya maupun pengetahuannya. Lebih spesifik lagi, yakni hak mencari, memperoleh, memiliki, menyimpan, mengolah dan menyampaikan informasi dengan menggunakan segala jenis sarana yang tersedia. Hak tersebut merupakan pengolongan hak mengembangkan diri dalam landasan operasional UndangUndang Nomor 39 Tahun 1999 sebagaimana diatur dalam ketentuan Pasal 11 sampai dengan Pasal 16 (Jurnal Hukum Progresif Vol XI No.2 Tahun 2017. Ditulis oleh Toni, SH, $\mathrm{MH})$.

Menilik lebih jauh dilihat dari ciri negara hukum salah satunya adalah menjamin dan melindungi hak asasi manusia, kepastian hukum dalam perlindungan hak memperoleh informasi, terlihat sinkron dengan Undang-Undang Nomor 14 Tahun 2008 tentang Keterbukaan Informasi Publik. Berarti manusia sebagai orang perorangan yang merupakan salah satu komponen publik berhak mendapatkan akses informasi dari negara pada umumnya dan penyelenggara pemerintahan pada khususnya (Jurnal Hukum Progresif Vol XI No.2 Tahun 2017. Ditulis oleh Toni, SH, MH).

Secara garis besar, ada tujuh tujuan pokok dari UU ini, antara lain: 
1. Menjamin hak warga negara untuk mengetahui rencana pembuatan kebijakan publik, program kebijakan publik, dan proses pengambilan keputusan publik, serta alasan pengambilan suatu keputusan publik;

2. Mendorong partisipasi masyarakat dalam proses pengambilan kebijakan publik;

3. Meningkatkan peran aktif masyarakat dalam pengambilan kebijakan publik dan pengelolaan badan publik yang baik;

4. Mewujudkan penyelenggaraan negara yang baik, yaitu transparan, efektif dan efisien, akuntabel serta dapat dipertanggungjawabkan;

5. Mengetahui alasan kebijakan publik yang memengaruhi hajat hidup orang banyak;

6. Mengembangkan ilmu pengetahuan dan mencerdaskan kehidupan bangsa;

7. Meningkatkan pengelolaan dan pelayanan informasi di lingkungan badan publik untuk menghasilkan layanan informasi yang berkualitas.

\section{METODOLOGI}

\section{PENELITIAN}

Menurut Emzir (2016:3), penelitian deskrptif kualitatif. Data yang dikumpulkan lebih mengambil bentuk kata-kata atau gambar daripada angka-angka. Hasil penelitian tertulis berisi kutipan-kutipan dari data untuk mengilustrasikan dan menyediakan bukti presentasi. Data tersebut mencakup transkrip wawancara, catatan lapangan, fotografi, videotape, dokumen pribadi, memo, dan rekamanrekaman resmi lainnya. Data dikumpulkan melalui teknik purposive sampling terhadap pengelola informasi dan dokumentasi yang ada di Desa Kasugengan Kidul Kecamatan Depok Kabupaten Cirebon.

Bogdan dan Taylor dalam Moleong (2017:4) juga mendefinisikan metode kualitatif sebagai prosedur penelitian yang menghasilkan data deskriptif berupa kata-kata tertulis atau lisan dari orang-orang dan perilaku yang dapat diamati. Menurut mereka, pendekatan ini diarahkan pada latar dan individu tersebut secara holistik (utuh). Sementara Denzin dan Lincoln (1987) dalam Meleong (2017:5) mendefinisikan penelitian kualitatif sebagai penelitian yang menggunakan latar alamiah, dengan maksud menafsirkan fenomena yang terjadi dan dilakukan dengan jalan melibatkan berbagai metode yang ada.

Atwar Bajari (2015:96-97) menjelaskan, penelitian sosial telah mengembangkan beberapa teknik pengumpulan data penelitian. Teknikteknik yang sering digunakan untuk penelitian, yaitu observasi, angket (kuesioner), wawancara, analisis isi, kepustakaan, serta teknik-teknik proyektif. Dalam pengumpulan dan penggalian data di lapangan, tiap-tiap teknik memiliki tingkat keakuratan dan kekuatan serta kelemahan yang berbeda-beda. Lofland dan Lofland dalam Meleong (2017:157) mengatakan bahwa sumber data utama dalam penelitian kualitatif adalah kata-kata dan tindakan, selebihnya adalah data tambahan, seperti dokumen dan lainlain. Untuk mendapatkan sumber dan jenis data pada penelitian ini, penulis melakukan pencatatan baik secara tertulis maupun melalui perekaman audio tapes, dan pengambilan gambar/foto. Pencatatan sumber data utama melalui wawancara atau pengamatan berperanserta merupakan hasil usaha gabungan yang dilakukan penulis dari kegiatan melihat, 
mendengar, dan bertanya kepada sejumlah narasumber yang penulis anggap kompeten untuk mendukung penelitian ini.

Adapun analisis data pada penelitian ini merupakan proses sistematis pencarian dan pengaturan transkripsi wawancara, catatan lapangan, dan materi-materi lain yang telah peneliti kumpulkan untuk meningkatkan pemahaman peneliti sendiri mengenai materi-materi tersebut. Janice McDrury (dalam Meleong, 2017:248) membagi empat tahap analisis data: 1) membaca/mempelajari data, menandai kata-kata kunci dan gagasan yang ada dalam data, 2) mempelajari kata-kata kunci itu, berupaya menemukan tematema yang berasal dari data, 3) menuliskan 'model' yang ditemukan, dan 4) melakukan pengodean.

\section{PEMBAHASAN}

\section{Gambaran Umum}

Desa Kasugengan Kidul merupakan salah satu desa yang berada di wilayah Kecamatan Depok Kabupaten Cirebon. Desa ini berbatasan langsung dengan Desa Kasugengan Lor di sebelah utara, Desa Depok, Desa Waruroyom, dan Desa Keduanan di sebelah selatan, Desa Lurah di sebelah timur, dan Desa Serang serta Desa Beberan di sebelah barat.

Desa Kasugengan Kidul memiliki total luas 127,40 hektare dengan luas permukiman 55 hektare, persawahan 37,80 hektare, perkebunan 1,40 hektare, pekarangan 2 hektare, dan luas prasarana umum lainnya 31,20 hektare. Adapun jumlah populasinya berdasarkan data tiga tahun terakhir mencapai 6.832 jiwa atau 3.179 kepala keluarga. Mayoritas warga di sini berlatar pendidikan terakhir SD dan
SMP dengan mata pencaharian sebagai petani atau buruh.

Perencanaan Informasi yang Dilakukan oleh Pengelola Informasi dan Dokumentasi Pemerintah Desa Kasugengan Kidul

Memasuki periode kedua di bawah pemerintahan Kepala Desa Nuryanto, program pembangunan di Desa Kasugengan Kidul terus digenjot. Untuk pos anggaran 2017-2018 misalnya, pemdes setempat telah mengalokasikan anggaran untuk pembangunan fisik di hampir semua dusun, antara lain;

1) Pengaspalan jalan di Dusun Watukruyu

2) Pengaspalan jalan di Dusun Mlayon

3) Pengaspalan jalan di Dusun Karangmas

4) Pengaspalan jalan di Dusun Pecung Kulon

5) Realisasi program rutilahu di RT 01, RT 02, RT 06, dan RT 11

6) Revitalisasi jembatan penghubung di Dusun Cikondar

7) Revitalisasi jembatan penghubung di Dusun Sidapurna

8) Revitalisasi jembatan penghubung di Dusun Mlayon

9) Revitalisasi jembatan penghubung di Dusun Cikondar RT 01

Selain pembangunan infrastruktur, Pemdes Kasugengan Kidul juga melakukan pemberdayaan masyarakat, terutama pembinaan berupa edukasi bahaya narkoba di kalangan remaja. Karangtaruna adalah salah satu wadah bagi para pemuda desa yang ingin aktif dalam pembangunan desanya. Karangtaruna Desa Kasugengan Kidul baru dibentuk tanggal 7 Agustus 2018. Jadi setiap ada informasi dari karangtaruna pusat, setiap koordinator wilayah akan langsung mengetahui dan dapat menginformasikan kepada para pemuda 
yang tidak aktif.

Setiap perangkat desa difungsikan perannya sebagai humas desa yang berkewajiban memberikan informasi secara jelas sebagai bagian dari pelayanan kepada masyarakat. Pemberdayaan masyarakat desa adalah upaya mengembangkan kemandirian dan kesejahteraan masyarakat dengan meningkatkan pengetahuan, sikap, keterampilan, perilaku, kemampuan, kesadaran, serta memanfaatkan sumber daya melalui penetapan kebijakan, program, kegiatan, dan pendampingan yang sesuai dengan esensi masalah dan prioritas kebutuhan masyarakat desa.

Pelatihan selanjutnya dilakukan bagi kader/anggota PKK. Contohnya adalah pembekalan pelatihan bercocok tanam, dengan tujuan menggerakan kader PKK supaya dapat mengetahui cara bercocok tanam yang baik. Mereka diharapkan dapat merangsang peran serta masyarakat secara umum. Usaha mewujudkan pembangunan desa lainnya yaitu mengadakan musyawarah terkait dengan program-program pembangunan desa dan partisipasi aktif dari masyarakat.

Musyawarah desa yang menjadi forum permusyawaratan merupakan hal yang paling fundamental. Dalam musyawarah, BPD, pemerintah desa, dan unsur masyarakat desa harus berperan serta secara aktif dalam merancang dan melaksanakan programprogram pembangunan desa secara bertanggung jawab.

$$
\text { Adapun tahap-tahap }
$$

pelaksanaan pembangunan desa di Kasugengan Kidul adalah sebagai berikut:

1) Mengadakan musyawarah rencana pembangunan (musrenbang). Pada tahap ini masing-masing RT mengajukan proposal pembangunan di dusunnya.

2) Kepala desa selaku pimpinan di desa melakukan proses verifikasi untuk menentukan program pembangunan desa apa yang tepat diberikan di setiap RT dengan menyesuaikan anggaran yang tersedia.

3) Selanjutnya kepala desa meneruskan usulan tersebut melalui RAPB-Des, APB-Des, Siskeudes, Pusat 3 yang dilakukan secara online.

Setelah dana desa turun, kepala desa bersama aparatur desa atau humas desa kembali mengadakan musyawarah dengan masyarakat untuk menginformasikan teknis realisasi pembangunan desa.

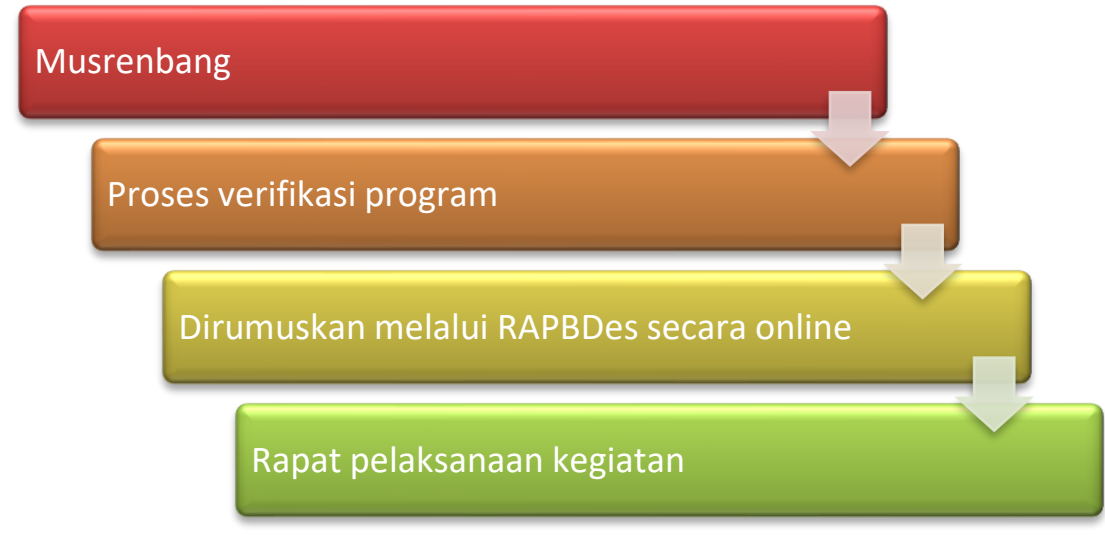

Gambar 1. Model tahap-tahap pelaksanaan pembangunan desa 
Transparansi Informasi Pembangunan Desa sebagai Implementasi Keterbukaan Informasi Publik

Undang-Undang desa menjamin hak warga atas informasi dan menegaskan kewajiban pemerintah desa untuk memenuhi hak warga atas informasi. Ini tertulis dalam Pasal 82 Undang-Undang desa yang menyatakan bahwa masyarakat desa berhak mendapatkan informasi mengenai rencana dan pelaksanaan pembangunan desa (Palupi et al, 2016:65).

Tata kelola pemerintahan yang baik (good governance) mensyaratkan pemerintahan yang terbuka sebagai salah satu pondasinya, dan kebebasan memperoleh informasi (public access to information) merupakan salah satu prasyarat untuk menciptakan pemerintahan terbuka (open government). Pemerintahan terbuka adalah penyelenggaraan pemerintahan yang transparan, terbuka, dan partisipatoris. Semakin terbuka penyelenggaraan negara untuk diawasi publik, maka penyelenggaraan negara tersebut makin dapat dipertanggungjawabkan (Subagiyo, 2009:4).

Pemerintah pusat, pemerintah provinsi, pemerintah kabupaten/kota, pemerintah desa, dan masyarakat harus satu tujuan dalam mengembangkan potensi dan pembangunan desa berdasarkan asas transparansi. Selanjutnya, secara bersama-sama melakukan pengawasan penyelenggaraan pembangunan desa yang dilakukan secara partisipatif oleh masyarakat desa.

Kegiatan pembangunan desa merupakan salah satu program kerja utama desa. Dalam proses pembangunan banyak sekali pihahpihak yang terlibat di dalamnya. Pembangunan itu sendiri ada dua tim pelaksana oleh kontraktor mitra dan oleh tim pelaksana kegiatan. Dalam pelaksanaan pembangunan di Desa Kasugengan Kidul ini selalu melibatkan masyarakat secara swadaya.

Selama kegiatan pembangunan berlangsung tim pelaksana wajib memasang papan kegiatan yang berisikan tentang kegiatan pembangunan dan jumlah dana yang digunakan sebagai bentuk transparansi pihak pemerintahan desa terhadap masyarakat dan sebagai sarana informasi untuk masyarakat. Sehingga warga bisa mengawasi langsung proses kegiatan pembangunan desa agar tidak terjadi penyalahgunaan.

"Ada kalanya kami menghadapi masalah terkait dengan kegiatan yang di luar dari perencanaan, atau adanya perubahan perencanaan. Sikap yang diambil ketika kegiatan tidak sesuai dengan perencanaan misalnya rencana 2018 ingin dibagun aspal di Rt 12 sepanjang jalan kedepan terus tidak terlaksana, kita alokasikan untuk tahun berikutnya supaya tetap dapat terealisai. Dan apabila ada perubahan perencanaan misalnya dana tidak cukup kita wajib membuat berita acara bahwa pembangunan tidak jadi dilaksanakan dan dialihkan untuk pembangunan yang lain yang memang dananya sesuai dengan dana yang ada pada waktu itu. Setiap akan dilaksanakan pembangunan ada rapat yang dilakukan tetapi kalaupun tidak diadakan rapat, nantinya tim TPK akan langsung mendatangi $\mathrm{Rt} / \mathrm{Rw}$ dan kepala dusun untuk memberitahu wilayah mereka yang mendapat jatah pembangunan. Setelah informasi sudah jelas tersampaikan barulah tim TPK memasang papan kegiatan," kata Nuryanto

Transparansi menurutnya tidak hanya soal pembangunan, pelayanan di desa pun tetap mengedepankan keterbukaan. Pemerintah desa sedang mencoba untuk menghindari praktik 
percaloan yang kian marak di lingkungan masyarakat desa. Pelaku percaloan biasanya mengintai masyarakat yang akan mengurus suratsurat atau dokumend ari desa seperti pembuatan KK dan KTP. Oleh karena itu menurut Nuryanto sikap transparan menjadi sangat penting guna menghindari hal-hal yang tidak diinginkan

"Masyarakat sekarang sudah mulai kritis apabila aduannya tidak didengar pemeritah desa, mereka bisa langsung mengadukannya ke dewan. Bentuk transparasi yang diterapkan bukan hanya persoalan dana saja tapi untuk seluruh pelayanan kami juga berusaha untuk selalu transparan. Misalnya ada warga datang ke desa ingin membuat kartu keluarga itu akan dijelaskan secara tegas prosedur pembuatannya dan tidak bisik-bisik mengenai pembiayaan yang sesuai dengan ketentuan yang ada dan seluruh pemerintah desa mengetahuinya, jadi ketika ada aparat desa yang memungut uang lebih dari biaya yang sudah ditetapkan tentu akan bisa dikenai teguran. Untuk menghindari kesalahan informasi pelayanan, prosedur pembuatan KK, KTP dan sebagainya warga harus terlebih dahulu mendapat surat pengantar dan persetujuan dari $\mathrm{Rt} / \mathrm{Rw}$ bahwa ada warganya yang ingin membuat KK, KTP dan sebagainya," imbuhnya

Dari pernyataan kepala desa tersebut di atas, kebijakan ini sejatianya adalah impelemntasi dari Undang-
Undang Dasar 1945 yang mengamanatkan bahwa negara wajib melayani setiap warga negara dan penduduk untuk memenuhi kebutuhan dasarnya dalam rangka pelayanan umum dan meningkatkan kesejah teraan masyarakat. Penyelenggaraan public service (pelayanan publik) yang dilaksanakan oleh aparatur pemerintah baik di tingkat desa maupun pusat, pada prinsipnya adalah bertujuan untuk pemenuhan hak-hak sipil dan kebutuhan dasar masyarakat, meskipun di saat bersamaan kinerjanya masih belum seperti yang diharapkan.

$$
\text { Pelayanan publik harus }
$$

dilaksanakan secara transparan oleh setiap unit pelayanan instansi pemerintah karena kualitas kinerja pemerintah melalui aparatur desanya memiliki implikasi yang luas dalam mencapai kesejahteraan masyarakat. meski demikian, kiranya masih perlu penjabaran secara detil mengenai keterbukaan informasi publik, karena pada dasarnya keterbukaan penyelenggaraan pelayanan publik akan dapat meningkatkan kinerja pelayanan publik. Transparansi harus dilaksanakan pada seluruh aspek manajemen pelayanan publik, mulai dari kebijakannya, perencanaannya, pelaksanaannya, pengawasannya, sampai dengan laporan hasil kinerjanya Secara sederhana, model transparansi yang diinisiasi oleh pengelola informasi dan dokumentasi Desa Kasugengan Kidul adalah sebagai berikut: 


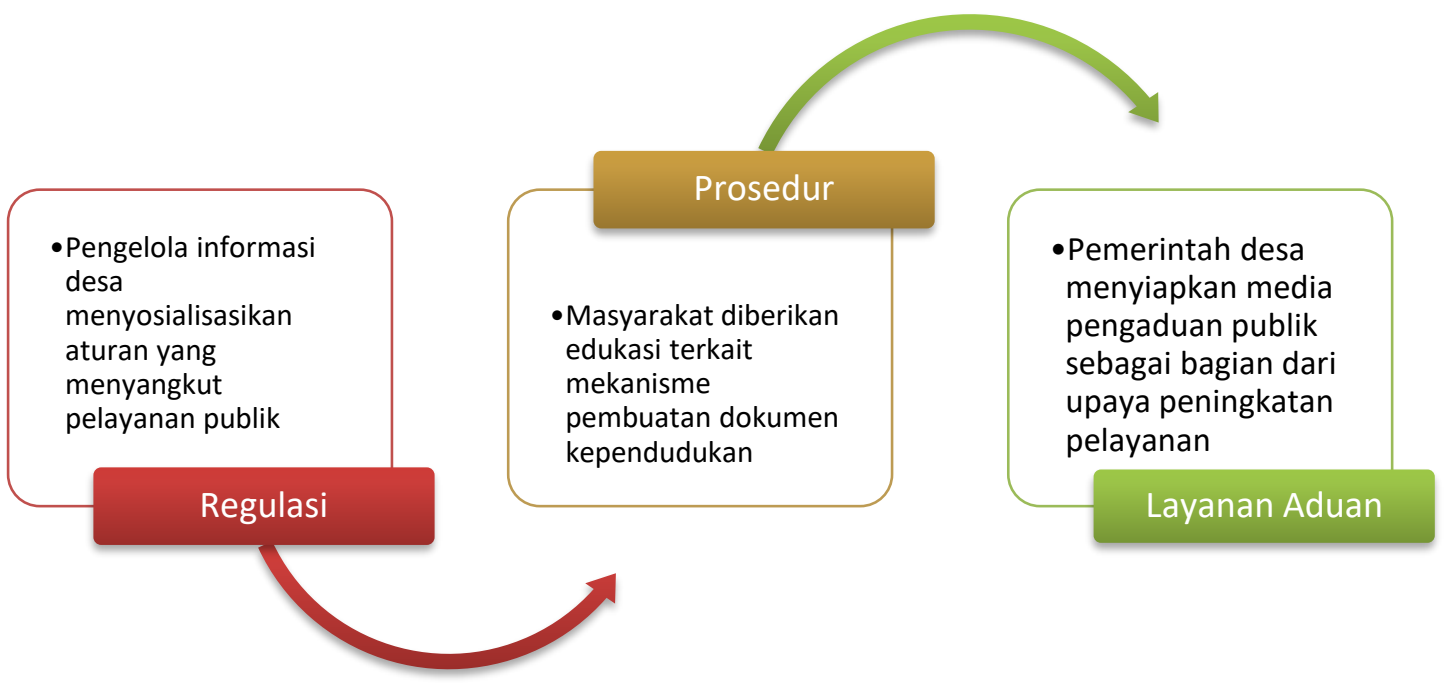

\section{Gambar 2. Model Transparansi yang Diinisiasi oleh Pengelola Informasi dan Dokumentasi Desa Kasugengan Kidul}

\section{E. KESIMPULAN}

Setiap perangkat desa idealnya dapat memainkan fungsinya sebagai humas desa atau pengelola informasi dan dokumentasi yang berkewajiban memberikan informasi secara terbuka dan jelas kepada masyarakat. Pemberdayaan masyarakat desa adalah upaya mengembangkan kemandirian dan kesejahteraan masyarakat dengan meningkatkan pengetahuan, sikap, keterampilan, perilaku, kemampuan, kesadaran, serta memanfaatkan sumber daya melalui penetapan kebijakan, program, kegiatan, dan pendampingan yang sesuai dengan esensi masalah dan prioritas kebutuhan masyarakat desa.

Musyawarah desa menjadi fundamental sebagai forum permusyawaratan lapisan masyarakat. Dalam musyawarah yang melibatkan unsur BPD, LPMD, dan stakeholder, pengelola informasi harus berperan serta secara aktif dalam merancang dan melaksanakan program-rpogram pembangunan desa dengan penuh tanggung jawab.

\section{SARAN}

Pemerintah pusat, pemerintah provinsi, pemerintah kabupaten/kota, pemerintah desa, dan masyarakat hendaknya bersinergi dalam mengembangkan potensi dan pembangunan desa berdasarkan asas transparansi, akuntabilitas, dan partisipatif. Selanjutnya, bersama-sama melakukan pengawasan penyelenggaraan pembangunan desa yang dilakukan secara partisipatif atau swadaya.

Penelitian ini tentunya masih terdapat banyak kekurangan. Oleh karenanya penulis berharap ke depan ada peneliti lain yang meneruskan telaah ini, sehingga penelitian terkait keterbukaan informasi publik oleh pengelola informasi di tingkat desa dapat memberikan sumbangsih yang luas bagi pengembangan keilmuan di masa yang akan datang.

\section{DAFTAR PUSTAKA}

Riset Terdahulu:

Setiaman, dkk. 2013. Implementasi Kebijakan Keterbukaan Informasi Publik. Jurnal Kajian Komunikasi Vol I No.2

Kristiyanto, Eko. 2016. Urgensi Keterbukaan Informasi dalam Penyelenggaraan Pelayanan 
Publik. Jurnal Penelitian Hukum De Jure Vol.16 No.2

Toni. 2017. Jurnal Hukum Progresif . Vol XI No.2

Referensi Buku:

Bajari, Atwar. 2015. Metode Penelitian Komunikasi: Prosedur, Tren, dan Etika. Bandung: Simbiosa Rekatama Media

Emzir. 2016. Metodologi Penelitian Kualitatif: Analisis Data. Jakarta: Rajawali Pers

Gassing, Syarifuddin, dkk. 2016. Public Relations. Yogyakarta: Andi

Moleong, Lexy. 2017. Metodologi Penelitian Kualitatif. Bandung: Remaja Rosdakarya

Palupi, Sri, dkk. 2016. Buku Panduan Pelaksanaan Undang-Undang Desa Berbasis Hak. Jakarta: Lakpesdam PBNU

Subagiyo, Henri, dkk. 2009. Anotasi Undang-Undang Nomor 14 Tahun $2008 \quad$ Tentang Keterbukaan Informasi Publik (Edisi Pertama). Jakarta: Komisi Informasi Pusat Republik Indonesia 